\title{
Experiences in the use of Ecological Footprint as a sustainability indicator
}

\section{J.I. Torregrosa-López ${ }^{1}$, C. G. Bellver Navarró ${ }^{2}$ y V.G. Lo Iacono-Ferreira ${ }^{3}$}

\author{
Universitat Politècnica de València, Campus d’Alcoi, pz/ Ferrándiz y Carbonell i, o380 i \\ Alcoy, Alicante (España) \\ IJITORREG@IQN.UPV.ES - ²CARNABEI@UPVNET.UPV.ES - 3VALOIA@EPSA.UPV.ES
}

\section{ABSTRACT}

To achieve sustainability in countries, organizations and all kind of environments, indicators are needed. The Ecological Footprint is an indicator that evaluates two basic principles of sustainable development: the sustainability principle and the principle of equity. As Ecological Footprint concept complies with the bases of environmental performance indicator it can be integrated in environmental management system to be easily assessed. Nowadays, methodologies for different areas as countries, corporation and organizations as universities between others, can be found in recent literature. However, there is still a lack of standardization that allows comparisons, monitoring and a profitable result analysis.

In this paper, bases of Ecological Footprint indicator are described; benefits and shortcomings are analyzed to outline a roadmap of Ecological Footprint assessment.

\section{KEY WORDS:}

Ecological Footprint, sustainable development, earth capacity, demanded land, Carbon Footprint, biocapacity.

\section{RESUMEN}

Para alcanzar la sostenibilidad en países, organizaciones y demás entornos, es necesario contar con indicadores. La Huella Ecológica es un indicador que evalúa dos principios básicos del desarrollo sostenible: el principio de sostenibilidad y el principio de equidad. Dado que la Huella Ecológica se ajusta al concepto de indicador de desempeño ambiental, puede ser integrado en sistemas de gestión ambiental para ser evaluado con facilidad. Hoy en día, pueden encontrarse en literatura reciente distintas metodologías para las diferentes áreas: países, corporaciones y organización, como las universidades, entre otros. 
Sin embargo, se evidencia una falta de estandarización que permita llevar a cabo comparaciones, seguimientos y análisis de resultados provechosos.

En este trabajo, se describen las bases del indicador Huella Ecológica. Se analizan sus ventajas e inconvenientes para delinear un plan de evaluación de este indicador.

\section{PALABRAS CLAVES}

Huella Ecológica, Desarrollo Sostenible, Capacidad de la tierra, Demanda de superficie, Huella de Carbono, Biocapacidad

\section{INTRODUCTION}

A sustainable development is a real need in actual society. Over last sixty years, the earth's population has tripled, food consumption has increased fivefold and trade have increased almost twenty times. For this, humanity has exploited the biggest and best spaces, those who had spent the planet for thousands of years for other equally important tasks bit apparently not very productive for humans.

Supplying the market with the growing demand of food or new public works and infrastructure has led the conversion of wetlands into farmland, the indiscriminate felling of forests, overexploitation of fisheries resources and degradation or destruction of important natural areas throughout the planet. As a result, over the last century, there has been a significant loss of the environment as well as a decrease in their ability to bear the burden of human activities and environmental impacts assimilate them.

However, the available space for these growing activities has not increased; the planet is only one. Although technology improves efficiency, the resources are limited; those who do are constantly renewed, has a renewable rate that, in many cases, surpassed the growing demand by humans, such as water; other resources are exhausted by forced marches for lack of renewal, such as fossil fuels.
The capabilities that the planet has to provide the resources demanded and mitigate the environmental impacts produced are clearly limited. To reach sustainability and track its progress, indicators are needed. Among different available indicators, the Ecological Footprint measures two main principles of sustainable development: sustainability and equity principles.

\subsection{Applicability and issues}

Ecological Footprint fulfils basic principles of systems of environmental performance indicators for organizations recommended by the Commission of European Community for the voluntary implementation of Regulation (EC) 761/2001 of the European Parliament and Council, popularly known as EMAS:

- Support to make comparisons and reflect the development of environmental performance;

- Balance, between problematic and promising;

- Continuity, based on the same criteria and time periods or comparable units;

- Update, to be evaluated often enough to take timely, and;

- Clarity, to be understood by social environment with applies.

Ecological Footprint comprises two other indicators: Carbon Footprint and Productive Footprint. Adding both values measured in hectares, Ecological Footprint is obtained as shows in Fig. 1. Where CF is Carbon Footprint in kilograms of $\mathrm{CO} 2$ equivalent emissions by year, PF is Productive Footprint in global hectares by year and FAF is the Global Average Forest Absorption Factor in kilograms of $\mathrm{CO} 2$ equivalent emissions absorbed by global hectare.

$$
\text { Ecological Footprint }\left[\frac{\text { gha }}{\text { year }}\right]=\frac{C F\left[\frac{\mathrm{KgCO}_{2} e}{\text { year }}\right]}{F A F\left[\frac{\mathrm{KgCO}_{2} e}{g h a}\right]}+P F\left[\frac{\text { gha }}{\text { year }}\right]
$$

Figure 1. Ecological Footprint equation 
- Carbon Footprint assesses world average forest needed to assimilate equivalent carbon dioxide emissions generated by the object of study. For equivalent carbon dioxide emissions, greenhouse gases have to be considered with the global worming potential assigned for each greenhouse gas by the International Panel for Climate Change (HOUGHATON, J.T. et al, 2001).

- Productive Footprint assesses ecologically productive land needed to generate resources and land required to assimilate and treat generated wastes.

Although there is not a standard methodology recognized by scientific community to assess the different areas (countries, organizations, regions, etc.), European Commission includes Ecological Footprint as an indicator for monitoring environmental impacts in the Thematic Strategy on the Sustainability Use of Natural Resources after concluding in an research of Ecological Footprint potential for this goal (BEST et al., 2008) that is a useful indicator for assessing progress on the EU's resources policies and is unique among the reviewed indicators in its ability to relate resources use to carrying capacity between other conclusions.

Ecological Footprint is classified as an intuitively appealing indicator. Results of Ecological Footprint are obtained in hectares, a measurable and comprehensible unit useful both to assess sustainability and to sensitize social environment.

Carbon Footprint indicator has a higher degree of development. Thanks to organizations as British Standard Institute ${ }^{1}$ and World Business Council for Sustainable Development ${ }^{2}$, this indicator has more than one standard to be assessed either on organizations, countries or products.

The close relationship between Carbon Footprint and energy consumption makes of this indicator a valuable parameter in itself into current policy of reducing energy dependence of Europe.

Most recognized methodologies are GHG Protocol (GREENHALGH, S. et al, 2005) and PAS 2050 (BRITISH STANDARD INSTITUTE, 2008). Both standards together with ISO 14025:2006², the International Reference Life Cycle Data System and Global Footprint Network organization ${ }^{4}$ will be the bases to build a harmonised methodology for the calculation of the environmental footprint of products and organizations under the coordination of the European Commission ${ }^{5}$ that is taking place during 2011.

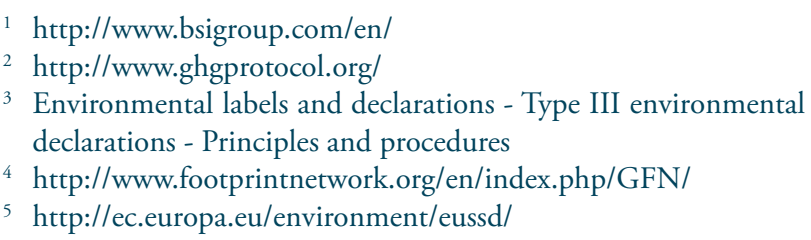

\subsection{Performance}

To perform an Ecological Footprint assessment (Fig. 2) the system boundaries must be defined correctly according to the aim of study; it must be taking into account the activity of the area, the objectives of the organization or de life cycle of the product. When the aim of study is a continent or a country, system boundaries are naturally defined by geography.

Figure 2. Roadmap to perform an Ecological Footprint assessment

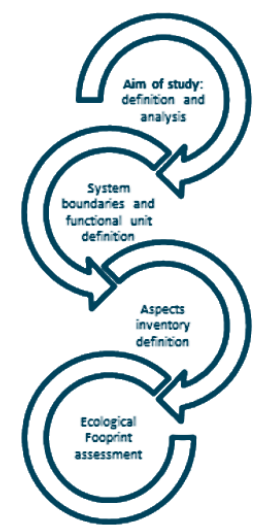

To adjust Ecological Footprint results to the aim of study, a functional unit has to be defined. Results specified by it allow comparisons and monitoring; a study to define a functional unit that represents the aim of study has to be carried out under the first study of Ecological Footprint and maintained for the followings revisions.

As well as the functional unit, an environmental aspect inventory has to be built to establish the necessary information needed to assess the Ecological Footprint. Inputs and Outputs of the system boundaries defined must be evaluated and it relevance must be considered.

Inputs and outputs must be well known and measured including waste production, pollutant emissions and wastewater discharges. This infor- 
mation is often widely dispersed along the different departments or units that compose the organization, country or area of study. A well implemented environmental management system can collect and process this data to feed Ecological Footprint assessment.

Ecological Footprint assessment can be perform with an organized environmental management system and the willingness of environmental managers in the case of organization, companies or small areas as municipalities. In the case of big areas as countries, a different information source is needed; most countries have public accounts and national institutes of statistics that's collect necessary information.

\section{ASSESSMENT METHODOLOGIES}

Nowadays, there are several methodologies for assessing Ecological Footprint as a result of variations in the original proposal made by WACKERNAGEL $\&$ REES (1996). Ecological Footprint can be used to assess the sustainability of organizations, products, process and different areas (countries, regions and cities) to carry out with their economic activity: big areas as continents and countries, and small areas as cities, companies, organizations and economic sectors as tourism or textile sector.

Table 1 shows some of the most interesting studies and some of its characteristics.
Main assessment structure is common to all methodologies: an inventory of significant sustainability aspects is developed; information sources are identified; an inventory of conversion factors is built; and Ecological Footprint results are obtained. Basic structure can be seen in Fig. 3.

As mentioned above, no methodology to assess Ecological Footprint is recognized as a standard by international scientific community. Except in the case of countries and continents where Global Footprint Network, research organization founded and directed by $\mathrm{PhD}$ Mathis Wackernagel, take care of the assessments; the responsible of each study makes a free interpretation of the calculation method and the inventory of aspects that has to be assessed based on the original definition of WACKERNAGEL \& REES, 1996.

This implies that Ecological Footprint assessment of organizations and small areas are hardly comparable; even monitoring of Ecological Footprint in the same area has its problems if significant changes affect the activity of the aim of study.

The inventory of conversion factors needed to assess the Ecological Footprint is another barrier to have a correct and useful Ecological Footprint assessment. Conversion factor must be consistent in time and geographic area to the aim of study. This characteristics vary depending on the aspect to assess; electricity, for example, depend on the way is

\begin{tabular}{|c|c|c|c|}
\hline Areas & Aspects considered & Studies & Result balance \\
\hline $\begin{array}{l}\text { Countries and } \\
\text { continents }\end{array}$ & $\begin{array}{l}\text { Energy, Land use, Mobility } \\
\text { and others }\end{array}$ & $\begin{array}{l}\text { Global Footprint by countries and continents (EDWING B } \\
\text { et al, 2010) }\end{array}$ & $\begin{array}{l}\text { Can be positive } \\
\text { or negative }\end{array}$ \\
\hline $\begin{array}{l}\text { Cities and } \\
\text { municipalities }\end{array}$ & $\begin{array}{l}\text { Energy, Land use, Mobility, } \\
\text { Infrastructure and others }\end{array}$ & $\begin{array}{l}\text { City of Barcelona (MUNIZ \& GALINDO, 2005) } \\
\text { and autonomous community of Navarra (DMAOTV } \\
\text { NAVARRA, 2001) }\end{array}$ & $\begin{array}{l}\text { Can be positive } \\
\text { or negative }\end{array}$ \\
\hline Economic sectors & $\begin{array}{l}\text { Energy, Land use, Mobility, } \\
\text { Infrastructure and others }\end{array}$ & $\begin{array}{l}\text { Tourism (HUNTER et al., 2005), Tourism in the Province } \\
\text { of Siena, Italy (PATTERSON et al., 2008) and Textile } \\
\text { sector (HERVA et al., 2008) }\end{array}$ & Mostly negative \\
\hline $\begin{array}{l}\text { Companies and } \\
\text { corporations }\end{array}$ & $\begin{array}{l}\text { Energy, Land use, Mobility, } \\
\text { Infrastructure and others }\end{array}$ & Port of Gijón (DOMÉNECH \& ARENALES, 2008) & Mostly negative \\
\hline $\begin{array}{l}\text { Schools and } \\
\text { universities }\end{array}$ & $\begin{array}{l}\text { Energy, Land use, Mobility, } \\
\text { Infrastructure and others }\end{array}$ & $\begin{array}{l}\text { University of Redlands (VENETOULIS, 2001) and } \\
\text { Universitat Politècnica de València (LO IACONO- } \\
\text { FERREIRA \& TORREGROSA-LOPEZ, 2011) }\end{array}$ & Mostly negative \\
\hline
\end{tabular}

Table 1. Examples of Ecological Footprint assessments. 


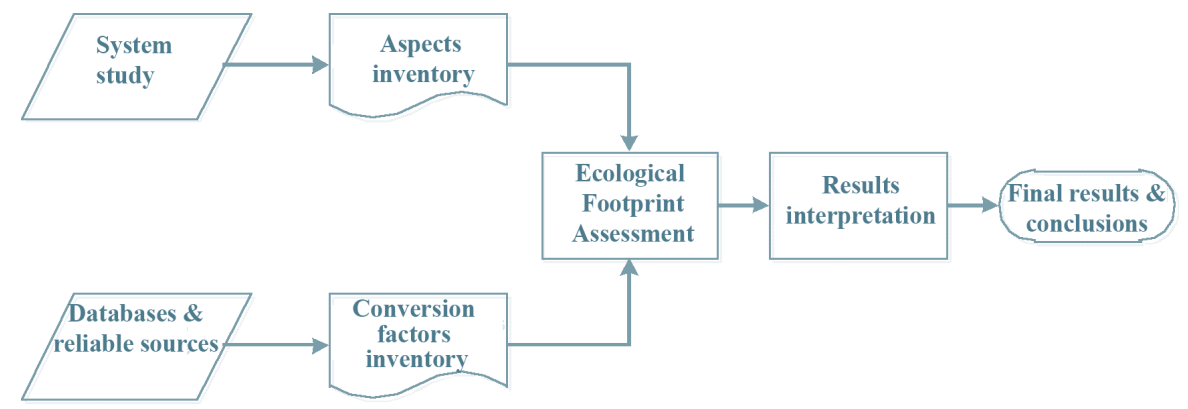

Figure 3. Main Ecological Footprint assessment structure.

produce and vary from year to year and according to the country where is produced. Other aspect, as the consumption of fossil fuels depends on the origin of the source and the kind of transport that is used to transport it to the place where is used, usually burned.

In general, there is no scientific consensus about the methodology to obtain conversion factors or the scope of the study of them; although it seems to be obvious that life cycle thinking should be applied. The methodology must beware of possible double counting of impacts and conversion factors must have certain desirable features such as:

- The source of the factors must be reliable and international recognized;

- The methodology used to obtain the conversion factor must be known and clear;

- The scope of the calculation must be in accordance with life cycle thinking;

- The conversion factor must be consistent in time and geographic area with the aim of study;

- The uncertainty must be known and uncertainty analysis applied.

In particular, conversion factors to assess the productive side of the Ecological Footprint, the Productive Footprint, must considered the land required to produce and assimilate the resources needed by the aspect. Life cycle thinking leads to the extraction of raw materials needed for it production. As explain above, the variation of the conversion factor in order to the geographic location can be significant. Nowadays, the availability of these factors is limited.

Although conversion factors to assess Carbon Footprint are more widespread, most of them does not comply with the desirable features explained above. The scope of the assessment has an additional significance in these conversion factors. According to Wackernagel definition, greenhouse gases emissions for each activity considered must be assessed; but most of conversion factors only count on $\mathrm{CO} 2$ emissions leaving on a side other greenhouse gases than, in less quantity, can be more dangerous as methane or nitrous. When all greenhouse gases are considered, conversion factors are assessed in kilograms of $\mathrm{CO} 2$ equivalent $(\mathrm{CO} 2 \mathrm{e})$ as defined by IPCC (HOUGHATON, J.T. et al, 2001).

The results of Ecological Footprint assessment can be positive or negative depending on if the biocapacity exceed the Ecological Footprint; that is to say, if the capacity of the area to generate resources needed is bigger than available land. A relation of result balance is identified in Table 1 where big areas as countries or cities can get a positive result, were biocapacity is higher than land required.

Small areas as organizations, economic sectors, regions and cities mostly needs more resources than what they can provide, getting a negative result that can be interpreted and improved year by year. Although it will always be negative, it can be enhanced. Below, significant examples of Ecological Footprint assessment in both, big and small areas are described.

\subsection{Ecological Footprint of big areas}

For big areas, as countries and continents, the most significant results that can be taken of the Ecological Footprint assessment are the Ecological Footprint of consumption and the Net Export of Ecological Footprint as a result of the difference between the biocapacity and the Ecological Footprint of consumption. 
As a practical example, Fig. 4 shows Ecological Footprint consumption data and the Net Export of Ecological Footprint of continents in 2007 obtained by evaluating biocapacity, production, exports and imports of each using national institute of statistics and public accounts as data sources.

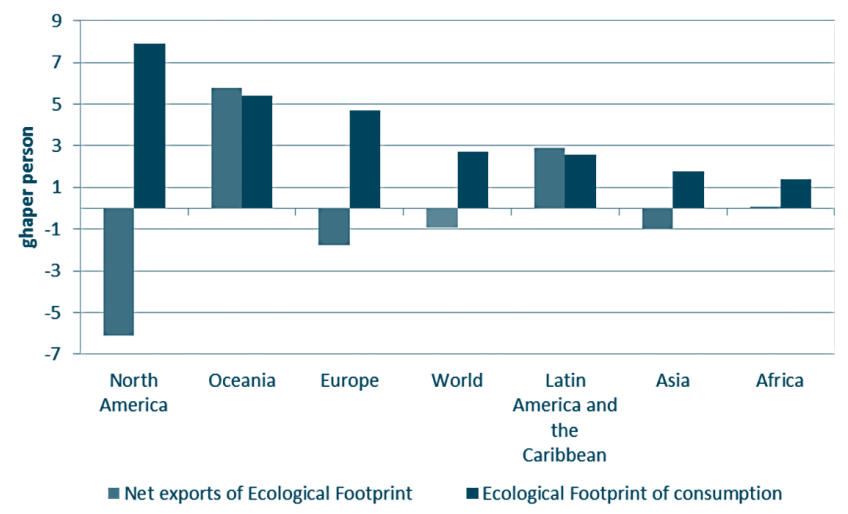

Figure 4. Net export of Ecological Footprint and Ecological Footprint for continents for 2007. (GLOBAL FOOTPRINT NETWORK, 2010)

Negative Net Export of Ecological Footprint values means that land required is bigger than available land denoting an imbalance. Latin America and the Caribbean, Asia and Africa are the continents with an average Ecological Footprint per person lower than world average, while Europe, Oceania and North America has a bigger Ecological Footprint average.

Although the Net Export of Ecological Footprint shows a pseudo-sufficiency in some areas as Latin America and the Caribbean, Oceania, Africa by a positive value, the Ecological Footprint does not contemplate the degree of development of each area. Unquestionably, certain civilization areas still have to develop and land requirements will be increased. For these cases, Ecological Footprint does not consider the social and economic developments needed to achieve a sustainable society.

Fig. 5 shows the Net Export of Ecological Footprint and Ecological Footprint per person for some countries: Costa Rica, China or Egypt has a lower Ecological Footprint than other as Mexico, Spain or Japan obtained by the same methodology than previous example.

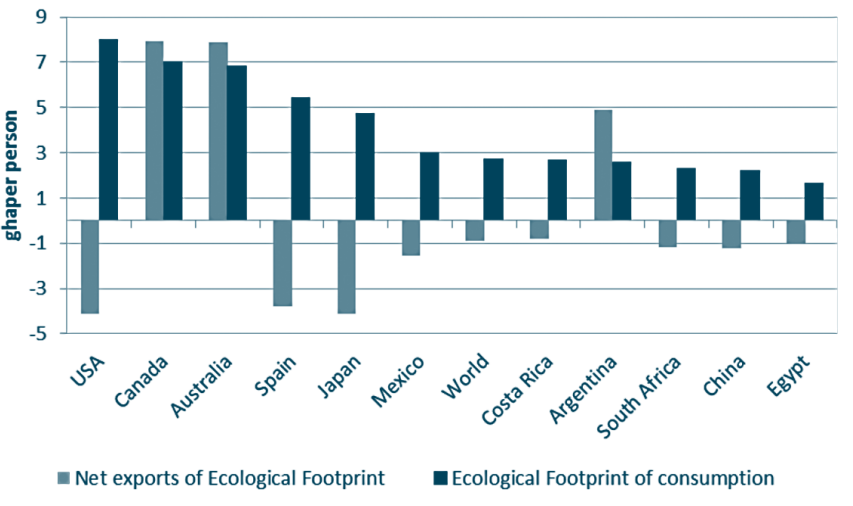

Figure 5. Net exports of Ecological Footprint for 2007. (GLOBAL FOOTPRINT NETWORK, 2010)

As in continent analysis, some of these countries have a negative Net Export. Only countries that are rich in territory and/or biodiversity have a positive result. A similar reflection than in the case of continents can be made, the degree of development of the society is not assess by de Ecological Footprint when land requirements might be linked to economic and social development.

\subsection{Ecological Footprint of small areas}

Universities are a good example of Ecological Footprint assessment in organizations. A university campus is a small area with a high level of complexity given the multiplicity of activities carried out in their environment: lectures, laboratory practices that may generate hazardous wastes, sports, small technology-based companies, research, etc.

A review of Ecological Footprint assessments in universities have been previously studied by the authors (LO IACONO FERREIRA \& TORREGROSA LÓPEZ, 2011) (TORREGROSA LÓPEZ et al, 2010). A summary with most significant studies is shown in Table 2.

For those assessments that have available information, a comparative table with aspects considered is presented in Table 3 where colour cells denote inclusion. 


\begin{tabular}{|c|c|c|c|c|}
\hline \multirow{2}{*}{ University } & \multirow{2}{*}{ Year or course } & \multirow{2}{*}{ Methodology } & \multicolumn{2}{|c|}{ Ecological Footprint } \\
\hline & & & Value & Unit \\
\hline Colorado College & 2001 & W\&R & 2,24 & ha/person.year \\
\hline East Anglia University & & Buitenhuis et al. & 7,3 & ha \\
\hline School of Physics - University of Sydney & 2002 & $\mathrm{~W} \& \mathrm{R}$ & 6,8 & ha/person \\
\hline $\begin{array}{l}\text { Escuela Politécnica de Valladolid - Universidad de } \\
\text { Valladolid }\end{array}$ & $2005 / 2006$ & - & 372,9 & ha/year \\
\hline $\begin{array}{l}\text { Escuela Universitaria Politécnica de Manresa - } \\
\text { Universidad Politécnica de Catalunya }\end{array}$ & Not specify & W\&R & \multicolumn{2}{|c|}{ not published } \\
\hline Holme Lancy College & 2001 & W\&R & 296 & ha \\
\hline Northeastern University & & Li et al. & 24787 & ha \\
\hline Ohio State University & 2007 & Janis & 8,66 & ha/person.year \\
\hline Oxford Brookes University & & W\&R & 0,22 & ha/person.year \\
\hline Redlands University & 1998 & Venetoulis & 20303 & ha \\
\hline Swansea University & & W\&R & 0,809 & ha/person.year \\
\hline Texas A\&M University & 2004 & $\mathrm{~W} \& \mathrm{R}^{*}$ & 0,69 & ha/student.year \\
\hline Toronto University & $2005 / 2006$ & Conway et al. & 1,07 & ha/person.year \\
\hline Universidad Autónoma de Madrid & $2002 / 2003$ & W\&R & 0,437 & ha/person.year \\
\hline Universidad da Coruña & & W\&R & 0,115 & ha/person.year \\
\hline Universidad de Girona & $1999 / 2003$ & W\&R & \multicolumn{2}{|c|}{ not pulished } \\
\hline Universidad de León & 2006 & W\&R & 0,45 & gha/person.year \\
\hline Universidad de Santiago de Compostela & 2007 & Propia & 0,16 & ha/person.year \\
\hline Universidad Miguel Hernández & 2007 & Venetoulis & 3,93 & gha/person.year \\
\hline Universidad Pablo de Olvide & & W\&R & \multicolumn{2}{|c|}{ not pulished } \\
\hline University of Holme & 2001 & $\mathrm{~W} \& \mathrm{R}$ & 0,56 & ha/person.year \\
\hline University of Newcastle & 1999 & Flint & 0,19 & ha/person.year \\
\hline Willamette University & $2003 / 2004$ & Not specify & 2,27 & ha/person.year \\
\hline
\end{tabular}

Table 2. Ecological Footprint of universities.

As an example of Ecological Footprint applicability in organizations the preliminary Ecological Footprint assessment made at Universitat Politècnica de València (UPV) (LO IACONO FERREIRA \& TORREGROSA LÓPEZ, 2011) can be used as example. UPV has an environmental management system verify in EMAS to manage environmental aspects of the entire university. As established by EMAS regulation, UPV EMS has developed an inventory of indicators to evaluate its environmental impacts of more than 200 of unites than integrates the university with a full range of associate impacts as hazardous waste, several energy consumption and transport between others.
UPV Ecological Footprint assessment evaluates five consecutive years between 2006 and 2010. The study considered seven different aspects associated to Carbon Footprint and Productive Footprint at can be seen in Table 4 .

As a functional unit to give dimension to Ecological Footprint results, this assessment considered the number of equivalent students (es), a relation between total students and the credits where they were enrolled considering that an equivalent student takes an average of seventy credits per year.

This assessment has allowed identifying main barriers to assess Ecological Footprint at organizations: 


\begin{tabular}{|c|c|c|c|c|c|c|c|c|c|c|}
\hline \multirow[b]{2}{*}{ University } & \multicolumn{10}{|c|}{ Aspects } \\
\hline & $\begin{array}{ll}\infty & 0 \\
0 \\
0 \\
0 \\
0\end{array}$ & 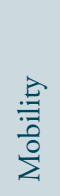 & 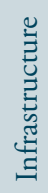 & 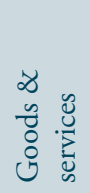 & 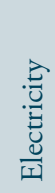 & 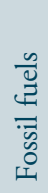 & 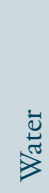 & 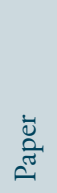 & 岕 & $\frac{\mathscr{U}}{\tilde{\Xi}}$ \\
\hline \multicolumn{11}{|l|}{ Universidad de León } \\
\hline \multicolumn{11}{|c|}{ Universidad de Santiago de Compostela } \\
\hline \multicolumn{11}{|l|}{ Universidad da Coruńa } \\
\hline \multicolumn{11}{|c|}{ Universitat Politècnica de València } \\
\hline \multicolumn{11}{|c|}{ Escuela Politécnica de Valladolid - UVa } \\
\hline \multicolumn{11}{|l|}{ Ohio State University } \\
\hline \multicolumn{11}{|l|}{ Willamette University } \\
\hline \multicolumn{11}{|c|}{ Escuela de Física - University of Sydney } \\
\hline \multicolumn{11}{|l|}{ Redlands University } \\
\hline \multicolumn{11}{|l|}{ Northeastern University } \\
\hline \multicolumn{11}{|l|}{ Toronto University } \\
\hline \multicolumn{11}{|l|}{ University of Newcastle } \\
\hline \multicolumn{11}{|l|}{ University of Holme } \\
\hline \multicolumn{11}{|l|}{ Holme Lancy College } \\
\hline Texas A\&M University & & & & & & & & & & \\
\hline
\end{tabular}

Table 3. Aspects considered in universities Ecological Footprint assessments

\begin{tabular}{l|c|c}
\multicolumn{1}{c|}{ Aspects } & $\begin{array}{c}\text { Carbon } \\
\text { Footprint } \\
\text { inclusion }\end{array}$ & $\begin{array}{c}\text { Productive } \\
\text { Footprint } \\
\text { inclusion }\end{array}$ \\
\hline Energy consumption & $\sqrt{ }$ & $\mathrm{x}$ \\
\hline Water consumption & $\sqrt{ }$ & $\mathrm{x}$ \\
\hline Paper consumption & $\sqrt{ }$ & $\mathrm{x}$ \\
\hline $\begin{array}{l}\text { Infrastructure } \\
\text { building }\end{array}$ & $\sqrt{ }$ & $\sqrt{ }$ \\
\hline $\begin{array}{l}\text { Food \& Drinks } \\
\text { consumption }\end{array}$ & $\sqrt{ }$ & $\sqrt{ }$ \\
\hline Waste management & $\sqrt{ }$ & $\mathrm{x}$ \\
\hline Mobility associated & $\sqrt{ }$ & \\
\hline
\end{tabular}

Table 4. Aspects considered in preliminary Ecological Footprint assessment at UPV
- Barrier 1. The functional unit: defining what is going to be assessed. In the case of the university, the functions of a university are not as well defined as in a company. This can be a barrier in order to refer de assessment to a service or product.

- Barrier 2. The system boundaries: defining the scope of the analysis, the range of the system under study and determine the processes and operations it comprises, such as prime material extraction, manufacturing and waste disposal.

- Barrier 3. Life cycle inventory and life cycle inventory assessment. Identifying mass and energy balance at the organization and transform them into environmental loads that can be assigned to assess the Ecological Footprint.

- Barrier 4. Capacity of the organization to provide necessary data in good conditions and assess it Ecological Footprint in terms of their environmental management. 
The above barriers can be extended to other organizations. As explain, one of the most relevant problems of Ecological Footprint assessment at organizations, small areas in general, is the definition of the scope of the analysis. This problem can be partially solved if a standard of assessment in organization is adapted. For this study, EMAS scope definition has been applied and results obtained are presented below. According to EMAS, the attribution of impacts has three well defined scopes:

- Scope 1: direct impacts, those where the organization is directly implicated

- Scope 2: energy impact, purchase from off-site (electricity, steam, etc.)

- Scope 3: indirect impacts, includes all other impacts as upstream and downstream impacts and those arising from employees transport, etc.

Depending on the functions of the organization, the relevance of each scope in Ecological Footprint assessment may vary considerably. As Scope 1, the university only has direct impacts mostly derived from some heating boilers and a building process or modification that can be made in infrastructures. Education, scientific investigation and technology transfers neither do not required significant resources nor produce significant emissions.

In contrast, energy consumption is relevant, resources needed to generate this energy and emissions associated to this process are considerable. Emissions are easily assessed by national energetic mix while resources need a more complex analysis based on a life cycle assessment.

Scope 3 is, probably, the most difficult scope to assess. The collaboration of all suppliers is needed and a mobility study is required.

For preliminary Ecological Footprint assessment of Universitat Politècnica de València, aspects grouped in Table 5 were considered in order to take advantage of data available on the environmental management system, the mobility study recently conducted and the collaboration of one of the inside restaurant managers. Special attention has to be paid to components of energy consumption. In contrast the results of Ecological Footprint for UPV presented above, to adjust to EMAS scopes definition, energy has been separated into energy purchase from off-site, electricity, and fuel consumption.

\begin{tabular}{|c|c|c|}
\hline Scope 1 & Scope 2 & Scope 3 \\
& & Water consumption \\
Fuel & & Paper consumption \\
Consumption & Electricity & consumption \\
for burning & consumption & Food \& drinks \\
Infrastructure & & consumption \\
emissions & & Waste management \\
& & External mobility \\
\hline
\end{tabular}

Table 5. Aspects considered in preliminary Ecological Footprint assessment of Universitat Politècnica de València.

Ecological Footprint results must be analysed in the context of the environmental management system. Scope 1 has to be the most relevant given that are the aspects where the organization can take decisions and influence directly with specific performances. Scope 2 and Scope 3 are associated to aspects where the organization can only influence in an indirect way. Green purchasing, environmental policy and green contracting are most powerful tools to apply in order to reduce this impacts.

\section{CONCLUSIONS}

For big areas, Ecological Footprint must be interpreted as an efficiency factor of sustainability. Carbon Footprint is an environmental indicator of the same grade but focus on fossil fuel energy consumption. As it is easier to assess, a previous consideration about which of both indicators is necessary and sufficient could save human resources and unnecessary work.

Ecological Footprint does not contemplate the development of an area. For those areas, as Africa or Latin America and de Caribbean that still has to develop, a sustainability indicator with the capacity to fully assess, not only environmental aspects but 
also the social and economic development is needed.

For small organizations, a proper methodology and a well done aspect inventory allow interesting and useful Ecological Footprint results. The methodology and it components must be consistent with the aim of study.

As an indicator, the Ecological Footprint is being displaced by Carbon Footprint indicator as it is easier to assess and strongly linked to fossil fuel consumption, the spotlight of European Community.

Barriers mention above must be solved in order to be able to assess Ecological Footprint in smaller areas: The scope of the Ecological Footprint should be defined as well as the system boundaries of the study; a functional unit must be established according to the aim of study.

Ecological Footprint results assess both in big areas as continents or countries and in other smaller areas as cities, companies or universities allow prioritizes inversions in those aspects more relevant working as a decision tool for management; although there is a lot of research and work to do to solve barriers detected.

High quality data is required. At small areas, this data can only be properly collected through the adoption of appropriate environmental management policies and environmental management system; EMAS assure the ability to collect correctly data needed. When the assessment is focus on big areas, clear national accounts and a well-built statistic institute provides all information needed.

\section{REFERENCES}

BEST, A., GILJUM, S., SIMMONS, C., BLOBEL, D., LEWIS, K., HAMMER, M., CAVALIERI, S., LUTTER, S \& CATHY MAGUIRE, C.. 2008. Potential of the Ecological Footprint for monitoring environmental impacts from natural resource use: Analysis of the potential of the Ecological Footprint and related assessment tools for the use in the EU's. Thematic Strategy on the Sustainable Use of Natural Resources. Report to the European Commission, DG, Environment. EU. 15pp.
BRITISH STANDARD INSTITUTE. 2008. PAS 2050: Specification for the assessment of the life cycle greenhouse gas emissions of goods and services. UK. 37pp.

DMAOTV NAVARRA. DEPARTAMENTO DE MEDIO AMBIENTE, ORDENACIÓN DE TERRITORIO Y VIVIENDA DE NAVARRA. 2001. La Huella ecológica de la comunidad foral de Navarra, aplicaciones técnicas y de comunicación. Departamento de Medio Ambiente, Ordenación del Territorio y Vivienda de la Comunidad foral de Navarra. ESPAÑA. 9pp.

DOMÉNECH, J., \& ARENALES, M. G. 2008. La Huella Ecológica de las empresas: 4 ańos de seguimiento en el puerto de Gijón. Observatorio Iberoamericano del Desarrollo Local y la Economía Social. ESPAÑA. 21pp.

HERVA, M., FRANCO, A., FERREIRO, S., ÁlVAREZ, A. \& ROCA, E. 2008. An approach for the application of the Ecological Footprint as environmental indicator in the textile sector. Journal of Hazardous Materials. 156:478-487.

HOUGHATON, J.T., DING, Y., GRIGGS, D.J., LEARY, N.A., DOKKEN, D.J. \& WHITE, K.S. 2001.. Third Assessment Report. Climate Change 2001:The Scientific Bases. IPCC - UNEP.Cambridge University Press. UK. 881 pp.

LO IACONO-FERREIRA, V. G. \& TORREGROSALÓPEZ, J. I. 2011. Methodological aspects of the use of Ecological Footprint at a university: a case of study at UPV. Universitat Politècnica de València. ESPAÑA. 99pp.

TORREGROSA-LÓPEZ, J.I., MARTI-BARRANCO, C. \& LO IACONO-FERREIRA, V.G. 2010. Un indicador ambiental para medir la sostenibilidad en las Universidades, la Huella Ecológica: Caso de estudio de la Universidad Politécnica de Valencia. CONAMA 10. ESPAÑA. 36pp.

EDWING B., MOORE, D., GOLDFINGER, S., OURSLER, A., REED, A. \& WACKERNAGEL, M. 2010. Ecological Footprint Atlas 2010. Global Footprint Network. USA. 113pp.

WACKERNAGEL, M., \& REES, W. 1996. Our ecological footprint: reducing human impact on the earth. New Society Publishers. CANADA. 165pp.

GREENHALGH, S., BROEKHOFF, D., DAVIET, F., RANGANTHAN, J., ACHARYA, M., CORBIER, L., OREN, K. \& SUNDIN, H. 2005. The GHG Protocol for Project Accounting. World Business Council for Sustainable Development and World Resources Institute. SWITZERLAND. 146pp 